\title{
EVALUATING ENVIRONMENTAL ACCOUNTING AND REPORTING: THE CASE OF CROATIAN LISTED MANUFACTURING COMPANIES
}

Summary: $\quad$ The importance of environmental accounting has been recognised on a global scale, and thus environmental reporting has become legally required. The implementation of environmental accounting results in environmental information that has become part of the company's non-financial report, as well as a component in creating a comprehensive overview of the company's business activities. The aim of this paper is to research into the environmental accounting and reporting within Croatian listed manufacturing companies. It analyses the manner in which companies report environmental information, as well as the share of environmental information in the financial reports of listed companies in 2017, focusing on the manufacturing industry as the one with the most significant environmental impact. The results show that listed manufacturing companies do not use environmental accounting sufficiently, which consequently leads to insufficient environmental reporting. Listed manufacturing companies in the Republic of Croatia mostly report environmental information in a quantitative manner. The results of the analysis of environmental information show that companies' reports often contain information on pollution and exhaust gases, while sustainability information is the least present information. In addition, few companies report on sustainability related to natural resource stocks and consumption and recycling. Thus, it is clear that caring for natural resources and protecting the environment for future generations are a low priority for management in the Croatian listed manufacturing companies. The companies surveyed report environmental information differently depending on the subsector they belong to. Furthermore, the implementation of environmental accounting and reporting has not increased on the basis of legal regulations.

Keywords: $\quad$ Environmental accounting, environmental reporting, listed companies, manufacturing industry

* Ana Zrnić, Teaching and Research Assistant, Faculty of Economics in Osijek, Josip Juraj Strossmayer University of Osijek, Trg Ljudevita Gaja 7, 31000 Osijek, Republic of Croatia. Email address: ana.zrnic@efos.hr.

** Dubravka Pekanov Starčević, PhD, Associate Professor, Faculty of Economics in Osijek, Josip Juraj Strossmayer University of Osijek, Trg Ljudevita Gaja 7, 31000 Osijek, Republic of Croatia. Email address: dubravka.pekanov@efos.hr.

*** Ivo Mijoč, PhD, Associate Professor, Faculty of Economics in Osijek, Josip Juraj Strossmayer University of Osijek, Trg Ljudevita Gaja 7, 31000 Osijek, Republic of Croatia. Email address: ivo.mijoc@efos.hr. 


\section{INTRODUCTION}

Environmental accounting and its implementation are of particular importance for the overall business performance of a company, especially the impact of doing business on the environment and its sustainability. Environmental protection and care are of particular interest to companies, which results in the incorporation of environmental issues into their goals and policies. According to research by Wiseman it can be seen that management of an increasing number of companies takes into account environmental issues when making decisions in relation to manufacturing and communication with interested parties. ${ }^{1}$

Therefore, the growth in awareness and concern in the general community is one of the primary factors suggested to influence a corporate response on environmental issues. ${ }^{2}$ The most important information associated with corporate sustainability is the one generated in the context of environmental accounting. ${ }^{3}$ Environmental accounting (EA) is also referred to as "ecological accounting", "environmental responsibility accounting", "eco-accounting", and "green accounting". Environmental accounting includes the identification, measurement and allocation of environmental costs, the integration of these costs into business, the recognition of environmental responsibility (if any), communication with stakeholders and conveying information to stakeholders, as an integral part of financial statements. ${ }^{4}$ Environmental costs make an important part of environmental accounting and are the result of certain activities that have been undertaken to protect the environment. Their definition depends on the company's various interests, which includes different costs such as cost of disposing but also external costs (those incurred outside the compan). ${ }^{5}$ They include all costs related to environmental protection and environmental pollution.

Corporate accounting system is the main source of obtaining environmental cost information. ${ }^{6}$ Environmental accounting is defined as a discipline that encompasses a range of business management tools, and its task is to provide useful information to support plans and decisions, regardless of interests or opinions of external parties (e.g. environmental or accounting regulatory bodies). ${ }^{7}$ This definition highlights two key issues. The first key point is that companies need to use environmental accounting for their own needs, not the needs of external users. The second key point is that the primary reason for applying environmental accounting in companies should be to create plans and make better decisions. Environmental

1 Wiseman, J., An evaluation of environmental disclosures made in corporate annual reports, Accounting, Organizations and Society, Vol. 7, No. 1, 1982, p. 54.

2 Wilmshurst, T. D.; Frost, G. R. Corporate environmental reporting: A test of legitimacy theory, Accounting, Auditing \& Accountability Journal, Vol. 13, No. 1, 2000, p. 12.

3 Hernádi, B. H., Green Accounting for Corporate Sustainability, Theory, Methodology, Practice, Vol. 8, No. 2, 2012 , p. 25.

4 Pramanik, A. K.; Shil, N. C.; Das, B., Environmental accounting and reporting with special reference to India, The Cost and Management, Vol. 3, No. November-December, 2007, p. 23.

5 Jasch, C., The use of Environmental Management Accounting (EMA) for identifying environmental costs. Journal of Cleaner production, Vol. 11, No. 6, 2003, p. 668.

6 Jing, H.; Songqing, L., The research of environmental costs based on activity based cost, Procedia Environmental Sciences, Vol. 10, 2011, p. 148.

7 Bailey, P. E.; Soyka, P. A., Environmental accounting-making it work for your company, Environmental Quality Management, Vol. 5, No. 4, 1996, p. 13. 
accounting is the process of identifying, measuring and communicating information about environmentally responsible performance of a business entity for the purpose of making economic decisions. ${ }^{8}$ Yakhou and Dorweiler extend the previous definition and state that environmental accounting provides reports for internal use by generating environmental information to help management make decisions referring to prices, cost control, capital budgeting, and external use, thus revealing information about the environment that is of interest to the public and the financial community. ${ }^{9}$ Based on the above definitions, it can be concluded that EA denotes the use of specific tools to generate important environmental information in order to enable certain business entities to make decisions and perform their business activity efficiently and environmentally friendly. EA is nothing more than quantification of environmental effects for the purpose of detecting the costs and benefits that may arise therefrom in order to make business decisions and inform the internal and external users thereabout. There is a theoretical model for EA application that links the two dimensions, namely EA and environmental reporting (ER). ${ }^{10}$ ER is actually the result of applying EA. EA can generally be divided into the following two areas: i) national environmental accounting, and ii) corporate environmental accounting. ${ }^{11}$ The former refers to the macroeconomic approach, while the latter refers to the microeconomic approach. Furthermore, corporate environmental accounting includes environmental financial accounting and environmental management accounting (EMA). EMA provides a set of tools designed to support management in making better decisions regarding cleaner production. ${ }^{12}$ Thereby, EMA's data is based on financial accounting and cost accounting but takes into account the environmental component in the business process in terms of reducing environmental costs and reducing environmental risks. EMA is mainly used to emphasize environmental protection costs due to the fact that other indicators such as waste issuing and stocking, raw materials and pollution of environment factors expenditures do not really show the value society has to bear. ${ }^{13}$ State regulation in terms of penalties for non-compliance with laws and regulations related to the environment is getting stricter. For these reasons, environmental cost management has become an indispensable part of EMA. Also, information on environmental costs is presented in the EMA financial reports.

The implementation of environmental accounting is encouraged in companies globally, and at EU level it is regulated by a special 2014/95/EU Directive. As a member of the European Union, the Republic of Croatia adapted the Accounting Act (OG 120/16) to the EU Directive. The new accounting law entered into force on 1 January 2017, meaning that the non-financial reporting obligation refers to companies' financial statements for the year 2017.

8 Qureshi, D. N. Z.; Kulshrestha, D. D.; Tiwari, S. B., Environmental accounting and reporting: An essential component of business strategy, Asian Journal of Research in Banking and Finance, Vol. 2, No. 4, 2012, p. 86.

9 Yakhou, M.; Dorweiler, V. P., Environmental accounting: an essential component of business strategy, Business Strategy and the Environment, Vol. 13, No. 2, 2004, p. 65.

10 Jones, op. cit., note 4, p. 125.

11 Peršić, M.; Janković, S., Menadžersko računovodstvo hotela. Zagreb: Fakultet za turistički i hotelski menadžment u Opatiji i Hrvatska zajednica računovođa i financijskih djelatnika Zagreb, 2006, p. 499.

12 Burritt, R. L.; Herzig, C.; Schaltegger, S.; Viere, T., Diffusion of environmental management accounting for cleaner production: evidence from some case studies, Journal of Cleaner Production, Vol. 224, July, 2019, p. 479.

13 Vasile, E.; Man, M., Current dimension of environmental management accounting. Procedia-Social and Behavioral Sciences, Vol. 62, October, 2012, p. 569. 
There are no significant studies in the Republic of Croatia covering the aforementioned reporting period, i.e. those that explore the application of environmental accounting after the new accounting law.

The aim of this paper is to investigate the implementation of environmental accounting in Croatian listed companies as one of the subjects required to disclose non-financial information. Emphasis is placed on manufacturing companies that are considered to have a greater impact on the environment than non-manufacturing companies. Financial statements of manufacturing companies are analysed in detail. Scientific contribution of the paper comes from the analysis of the application of EA in Croatian companies following the application of the new legislation, which has resulted in new knowledge and contribution to the field of environmental accounting that has been insufficiently researched in Croatia, especially after the application of the new Accounting Act.

The paper is divided into five main sections. After the introduction and the theoretical overview, there follows a section in which the applied methodology is explained. The next section gives research results, which summarise the main aspects of environmental reporting of Croatian listed companies in the manufacturing industry. The last section gives the main conclusions of the paper.

\section{LITERATURE REVIEW}

Corporations are increasingly demanding social legitimation, and thus a duty to do business in a way aimed at mitigating the impact on the environment, and consequently to report on such actions. ${ }^{14}$ In the process of conceptualising reports and reporting itself, management makes use of environmental accounting.

In the Republic of Croatia, prior to the implementation of the EU Directive, EA achieved positive results in terms of managerial attitudes towards environmental reporting. In their study, Krivačić and Janković (2017) studied the attitudes of Croatian managers towards environmental reporting and came to a conclusion that managers are more likely to believe that reasons for environmental reporting originate from ethical corporate responsibility rather than from the benefits that such business practice could bring. Environmental reporting of listed companies in the Republic of Croatia is not sufficiently developed, which is confirmed by the fact that few companies on the Zagreb Stock Exchange submit environmental reports. According to Krivačić (2012), only 22\% of the listed companies did that. Also, environmental information is insufficiently represented if Croatian companies are surveyed by a given sector. In the Croatian hospitality industry, environmental accounting is currently not well developed, and high quality environmental accounting information for the managerial decision-making process is therefore lacking. The findings of the paper are based on survey results conducted in large hotel companies in Croatia in late 2009 and early 2010. ${ }^{15}$

14 Jones, M. J., Accounting for the environment: Towards a theoretical perspective for environmental accounting and reporting, Accounting Forum, Vol. 34, No. 2, 2010, p. 123.

15 Jankovic, S.; Persic, M.; Zanini Gavranic, T., Framework for development of environmental management accounting in Croatian hospitality industry. Sustainable Tourism: Socio-Cultural, Environmental and Economics Impact, Vol. 1, 2011, p. 133. 
After the adoption of the EU Directive and the new Accounting Act, the application of EA in the Republic of Croatia has not been adequately researched. Since the EU Directive and the Accounting Act were adopted on 1 January 2017, it was to be expected that the obligators of the said statutory regulations would report non-financial information in their financial statements for 2017. In March 2018, a survey was conducted on the financial statements referring to year 2017 of the listed companies in the Republic of Croatia. Despite legal regulations referring to non-financial reporting, Croatian listed companies have insufficiently reported on environmental accounting information, i.e., $16.67 \%$ of 36 companies (out of a total of 138 companies that were analysed) do not disclose any environmental accounting information in their annual financial statements. ${ }^{16}$ For this reason, it can be concluded that the process of non-financial reporting on the environment is still at the development phase, and the results of the implementation of the Act will be seen in the upcoming period.

\section{METHODOLOGY}

In view of research goals aiming at determining the application of EA, the Croatian listed companies are involved in research. These are companies whose securities are traded on the Zagreb Stock Exchange (hereinafter referred to as: "the Stock Exchange") in accordance with both the rules and regulations of the Stock Exchange and the Capital Market Act. ${ }^{17}$ This is due to the fact that as of 1 January 2017, according to legal regulations (i.e. the Accounting Act and the EU Directive), the listed companies are required to disclose in their reports non-financial information, hence environmental information as well. ${ }^{18,19}$

Financial statements of these companies were downloaded from the Stock Exchange website by selecting unconsolidated financial statements of the companies covering the period from1 January to 31 December 2017. The reason for using unconsolidated financial statements is that some companies are not obliged to consolidate. Thus, a comparison of EA application would not be possible. Data were downloaded on 9 October 2018. In unconsolidated annual financial statements of the company, environmental data were requested in order to prove the hypotheses.

\subsection{SAMPLE DESCRIPTION}

There are 134 companies on the issuer list. Out of the total number of issuers, 51 manufacturing companies were selected for this paper. The reason for selecting manufacturing com-

16 Pekanov Starčević, D.; Zrnić, A.; Mihalina, E., Environmental Accounting in Croatia: A Review of Corporate Reporting Practices. Interdisciplinary Management Research XIV, 2018, p. 1407.

17 The issuer list is available onthe Zagreb Stock Exchange, URL=http://www.zse.hr/default.aspx?id=36769. Accessed 2 September 2018.

18 Art. 19a of the European Parliament, Official Journal of the European Union - Directive No. 2014/95/EU. 
panies is that they are assumed to have a greater impact on the environment than those that are not manufacturing. In support of this statement, Bewley and Li argue that manufacturing activities consume natural resources and energy and can thus cause environmental damage. ${ }^{20}$ Table 1 shows a breakdown of companies by sectors according to the National Classification of Economic Activities 2007.

Table 1. Listed companies in the Republic of Croatia by sectors - the National Classification of Economic Activities 2007

\begin{tabular}{|l|c|c|}
\hline \multicolumn{1}{|c|}{ Sector } & Number of companies & \% of companies \\
\hline Agriculture, forestry and fishing & 6 & 11.77 \\
\hline Construction & 5 & 9.80 \\
\hline Information and communication & 3 & 5.88 \\
\hline Manufacturing & 37 & 72.55 \\
\hline Total & $\mathbf{5 1}$ & $\mathbf{1 0 0}$ \\
\hline
\end{tabular}

Source: Prepared by authors based on Zagreb Stock Exchange andNational Classification of Economic Activities2007 data

Table 1 shows that manufacturing companies are divided into four sectors, i.e. agriculture, forestry and fishing, construction, information and communication and manufacturing. As most manufacturing companies belong to the processing sector $(72.55 \%)$, only those companies (37 of them) are included in the analysis, while other manufacturing companies are excluded from further analysis. More detailed insights into the financial statements show that out of 37 manufacturing companies only 21 publish some environmental information in their reports. Accordingly, 21 companies are included in the environmental reporting analysis.

\subsection{DESCRIPTION OF ENVIRONMENTAL VARIABLES}

As noted above, in unconsolidated annual financial statements of the observed companies, environmental data were requested for the purpose of proving the hypotheses. Since no environmental reporting framework has been defined, companies independently choose environmental information they will present in their reports. When selecting environmental variables, what was taken into account was their measurement for the purpose of comparing the companies. A literature review reveals that authors adapt environmental components depending on the scope of EA application, i.e. depending on the country where companies operate. Accordingly, environmental information and its classification according to $\mathrm{Lu}^{21}$ and

20 Bewley, K.; Li, Y., Disclosure of environmental information by Canadian manufacturing companies: a voluntary disclosure perspective, Advances in Environmental Accounting \& Management, Vol. 1, 2000, p. 210.

21 Lu, Ying J., A study of environmental disclosures made by Chinese mineral extraction corporations, University of Wollongong Australia, 2008, Res thesis, p. 83. 
Wiseman ${ }^{22}$ are used in the paper. These classifications are combined and adjusted such that the classification corresponds to Croatian business practice. This is shown in the Figure 1.

\begin{tabular}{|l|}
\hline $\begin{array}{l}\text { General } \\
\text { environmental } \\
\text { information }\end{array}$ \\
\hline - Company's envi- \\
ronmental policy \\
or environmental \\
concern \\
- Regulatory \\
compliance \\
- Impacts of \\
products and \\
services on the \\
environment \\
- ISO certificate \\
and environmen- \\
tal rewards \\
- Environmental \\
risks \\
\hline
\end{tabular}

\begin{tabular}{|l||l|}
\hline $\begin{array}{l}\text { Emissions } \\
\text { and pollution } \\
\text { reduction }\end{array}$ & $\begin{array}{l}\text { Environmental } \\
\text { sustainability }\end{array}$ \\
\hline $\begin{array}{l}\text { - Emissions data } \\
\text { - Wastewater data } \\
\text { - Data on waste } \\
\text { generation and } \\
\text { management/ } \\
\text { monitoring } \\
\text { Described con- } \\
\text { trols, installa- } \\
\text { tions, devices or } \\
\text { procedures }\end{array}$ & $\begin{array}{l}\text { Energy stocks } \\
\text { and/or consump- } \\
\text { tion data } \\
\text { - Water supply } \\
\text { and/or consump- } \\
\text { tion data } \\
\text { Natural resource } \\
\text { consumption/ } \\
\text { renewable energy } \\
\text { sources } \\
\text { Recycling }\end{array}$ \\
\hline
\end{tabular}

\begin{tabular}{|l|}
\hline $\begin{array}{l}\text { Other } \\
\text { environmental } \\
\text { information }\end{array}$ \\
\hline - Environmen- \\
tal protection \\
expenditures \\
- Environmen- \\
tal protection \\
investments \\
- Collaboration \\
with suppliers \\
\\
\end{tabular}

Figure 1. Classification of environmental information

Source: Prepared by authors

Environmental components are classified into four categories: general environmental information, emissions and pollution reduction, environmental sustainability and other environmental information. In order to test the hypotheses, financial statements of a company were analysed in a sample where a share of individual environmental variables in these financial statements was determined. Since environmental variables need to be quantified in a certain way, and for the purpose of comparison, the following way of measuring environmental variables was selected. Environmental variables were measured such that the way was defined in which companies present environmental information in their financial statements. Measurement was conducted according to Wiseman. According to this author, environment-related items that are generally mentioned in financial statements, those items that are not mentioned and those that are described qualitatively are designated by 1,0 , and 2 , respectively. ${ }^{23}$ In this paper, classification or coding of environmental variables was performed by using Wiseman'scoding scheme with numbers 0,1 and 2, and adding two new codes 3 and 4 . Code 3 refers to items described in quantitative units (physical or monetary), while code 4 indicates items quantitatively described in physical and monetary units. The coding scheme is shown in Table 2.

\footnotetext{
22 Wiseman, op. cit., note 1, p. 59.

23 Wiseman, op. cit., note 1, p. 55.
} 
Table 2. Coding of environmental variables

\begin{tabular}{|c|l|}
\hline Codes & Application modes in financial statements \\
\hline 0 & Item not mentioned \\
\hline 1 & Item mentioned generally \\
\hline 2 & Item described qualitatively \\
\hline 3 & Item described in quantitative units (physical or monetary) \\
\hline 4 & Item quantitatively described in physical and monetary units \\
\hline
\end{tabular}

Source: Prepared by authors

The coding scheme shows that the item described by means of physical and monetary units (code 4) has the highest numerical value assigned since it includes all of the aforementioned codes. Items with lower code values (e.g. code 1) point to a lower value of environmental variables in financial statements. Consequently, environmental information reports of the companies that have environmental variables with code 4 in their financial statements are of the best quality.

\subsection{OPERATIONALISATION OF VARIABLES}

For the purpose of hypothesis testing, according to the coding scheme and based upon environmental variables, four new composite environmental variables were created by means of summation.

The sum of general environmental information (i.e. company's environmental policy or environmental concern, regulatory compliance, impacts of products and services on the environment, ISO certificate and environmental rewards, and environmental risks) makes a new variable named sum_general. The sum_pollution variable contains emissions data, wastewater data, data on waste generation and management/monitoring, and described controls, installations, devices or procedures.

Variable sum_sustain ability includes energy stocks and/or consumption data, water supply and/or consumption data, natural resource consumption/renewable energy sources, and recycling. The fourth composite variable called sum_other consists of environmental protection expenditures, environmental protection investments, and collaboration with suppliers.

\section{RESULTS WITH DISCUSSION}

\section{Results}

The application of environmental accounting in financial statements will be analysed by testing next hypotheses: 
- H1: Listed manufacturing companies in the Republic of Croatia prepare reports on the environment mostly in a qualitative manner.

- H2: General environmental information is the most common information in reports provided by the listed manufacturing companies in the Republic of Croatia.

- H3: Manufacturing companies differ in subsectors in terms of environmental reporting.

As environmental reporting is considered in the theoretical part of the paper, manufacturing companies in the Republic of Croatia are expected to submit environmental reports more than companies in other industries, and following this, the research sample was focused exclusively on manufacturing companies.

Hypothesis 1 is focused on discussing the frequency of using qualitative environmental reporting. The variable used to measure the company's environmental reporting system contained five modes, where mode 0 referred to companies that neither use nor mention the analysed variable (i.e. an item in environmental reports) in their financial statements. At the same time, companies that marked 0 as an answer were labelled as missing values, thus neutralising their impact on creating an aggregate variable for a particular group in environmental reporting.

Therefore, in Table 4, the missing column actually refers to the number of companies that do not mention the analysed item in their financial statements, while the valid column refers to companies that can be classified by their reporting into:(1) a general category, (2) a category describing the item qualitatively or quantitatively, where (3) denotes physical or monetary units, whereas (4) denotes both physical and monetary units, thus representing the most developed way of measuring the analysed item.

Table 4. Descriptive statistics of variables (environmental item in financial statements)

\begin{tabular}{|l|c|c|c|}
\hline \multirow{2}{*}{ Environmental item } & \multicolumn{2}{|c|}{ N } & \multirow{2}{*}{ Mode } \\
\cline { 2 - 3 } & Valid & Missing & \\
\hline Company's environmental policy or environmental concern & 14 & 7 & 2 \\
\hline Regulatory compliance & 6 & 15 & 2 \\
\hline Impacts of products and services on the environment & 3 & 18 & 2 \\
\hline ISO certificate and environmental rewards & 9 & 12 & 1 \\
\hline Environmental risks & 5 & 16 & 1 \\
\hline Emissions data & 10 & 11 & 3 \\
\hline Wastewater data & 8 & 13 & 3 \\
\hline Data on waste generation and management/monitoring & 9 & 12 & 3 \\
\hline Described controls, installations, devices or procedures & 5 & 16 & 2 \\
\hline Environmental sustainability & 0 & 21 & - \\
\hline Energy stocks and/or consumption data & 11 & 10 & 3 \\
\hline
\end{tabular}




\begin{tabular}{|l|c|c|c|}
\hline \multirow{2}{*}{ Environmental item } & \multicolumn{2}{|c|}{ N } & \multirow{2}{*}{ Mode } \\
\cline { 2 - 4 } & Valid & Missing & \\
\hline Water supply and/or consumption data & 6 & 15 & 3 \\
\hline Natural resource consumption/renewable energy sources & 2 & 19 & $2^{\text {a }}$ \\
\hline Recycling & 3 & 18 & 1 \\
\hline Environmental protection expenditures & 2 & 19 & 3 \\
\hline Environmental protection investments & 3 & 18 & 3 \\
\hline Projections of future pollution control costs & 1 & 20 & 4 \\
\hline
\end{tabular}

Multiple modes exist. The smallest value is shown.

Source: Prepared by authors based on IBM SPSS Statistics 23.0

Only one measure of central tendency is presented, i.e. the one referring to the mode repetition frequency. To test hypothesis 1 , the last column in the table was analysed. Based on the data given in Table 4, sufficient evidence is provided to reject the H1 hypothesis for which 16 variables were analysed ${ }^{24}$ that represented environmental items in financial statements. This is the result of comparing the modes for the 16 variables offered, where for the following four items it was stated that the companies most frequently report in a qualitative manner:

- company's environmental policy or environmental concern,

- regulatory compliance,

- impacts of products and services on the environment,

- described controls, installations, devices or procedures,

while for as many as eight variables it was found out that environmental reports are prepared in one of the quantitative ways, either (3) or (4), thus encompassing $50 \%$ of environmental information analysed in financial statements. A more detailed description of variables is available in Appendix 3 of the paper.

Hypothesis 2 refers to a share of general environmental information in reports provided by the listed manufacturing companies in the Republic of Croatia, i.e. to general environmental information as the most common information in reports provided by the listed manufacturing companies in the Republic of Croatia. To test hypothesis 2, composite environmental variables were used that were created by summation. Descriptive statistics were used to determine which environmental information was most frequently used in financial statements of the companies surveyed. Table 5 lists the minimum and maximum values, the arithmetic mean and the standard deviation. 
Table 5. Share of environmental information in financial statements

\begin{tabular}{|l|c|c|c|c|c|}
\hline $\begin{array}{l}\text { Environmental } \\
\text { variables }\end{array}$ & N & Minimum & Maximum & $\begin{array}{c}\text { Arithmetic } \\
\text { mean }\end{array}$ & $\begin{array}{c}\text { Standard } \\
\text { deviation }\end{array}$ \\
\hline sum_general & 16 & 1.00 & 9.00 & 3.7500 & 2.20605 \\
\hline sum_pollution & 11 & 1.00 & 11.00 & 6.3636 & 3.32484 \\
\hline sum_sustainability & 13 & 2.00 & 9.00 & 4.6154 & 2.25605 \\
\hline sum_other & 5 & 1.00 & 6.00 & 3.4000 & 1.81659 \\
\hline Valid N (listwise) & 2 & & & & \\
\hline
\end{tabular}

Source: Prepared by authors based on IBM SPSS Statistics 23.0

Table 5 shows the number of companies $(\mathrm{N})$ reporting specific environmental information. The largest number of companies (i.e. 16 of them) mention general environmental information in their reports, while the smallest number (only 5) reports on environmental information in their financial statements. The minimum column indicates a number of environmental information minimally present in financial statements of the companies surveyed. Sustainability information is highlighted as the only information twice (minimum $=2$ ) present in financial statements of the companies surveyed, whereas other environmental information is present in reports at least once. The maximum column indicates which information is mostly present in company financial statements and it can be noticed that the most common information is the one on pollution $(11$, i.e. maximum $=11)$. On the other hand, general environmental information and sustainability information are equally present, while financial information on the environment is least common. In addition, on average, pollution-related information and other environmental information is present in 6 companies (mean $=6.3636$ ) and 4 companies (mean $=3.750)$, respectively. The aforementioned suggests that hypothesis 2 may be rejected on the basis of results as the companies are mostly not likely to disclose general environmental information.

Hypothesis 3 is focused on testing the differences in company environmental reporting depending on the subsector of the manufacturing industry to which the company in question belongs. For the purpose of analysis and by using descriptive statistics, subsectors of the manufacturing industry, i.e. 12 in this case, were used as a variable, depending on the companies analysed. For the purpose of testing hypothesis 3, graphs 1-4 show a certain composite environmental variable (the arithmetic mean on the $\mathrm{y}$-axis) and subsectors (the $\mathrm{x}$-axis). 
Graph 1. General environment-related components by subsectors

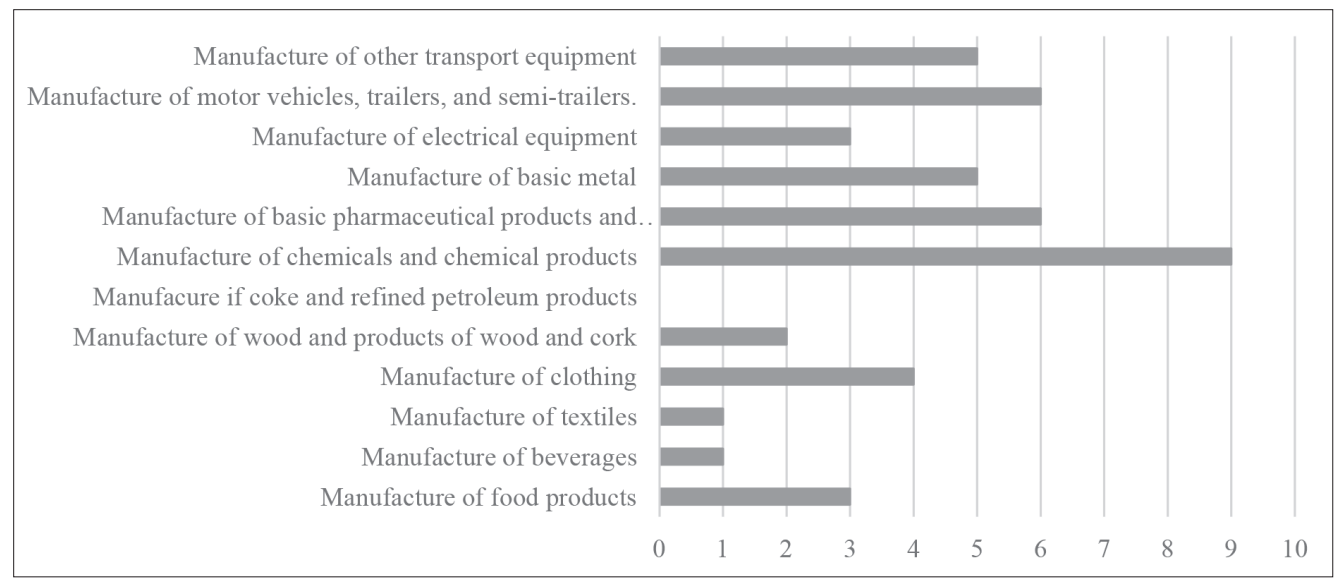

Source: Prepared by authors based on IBM SPSS Statistics 23.0

General environmental information is most frequently reported by companies from the subsector Manufacture of chemicals and chemical products (mean = 9). The reason for that may be the fact that this subsector has a significant impact on the environment, and therefore the companies in this subsector pay attention to describing and reporting the policies they apply to protect the environment. The least general environmental information is reported by companies engaged in Manufacture of beverages and Manufacture of textiles (mean $=1$ ).

Graph 2. Pollution-related information by subsectors

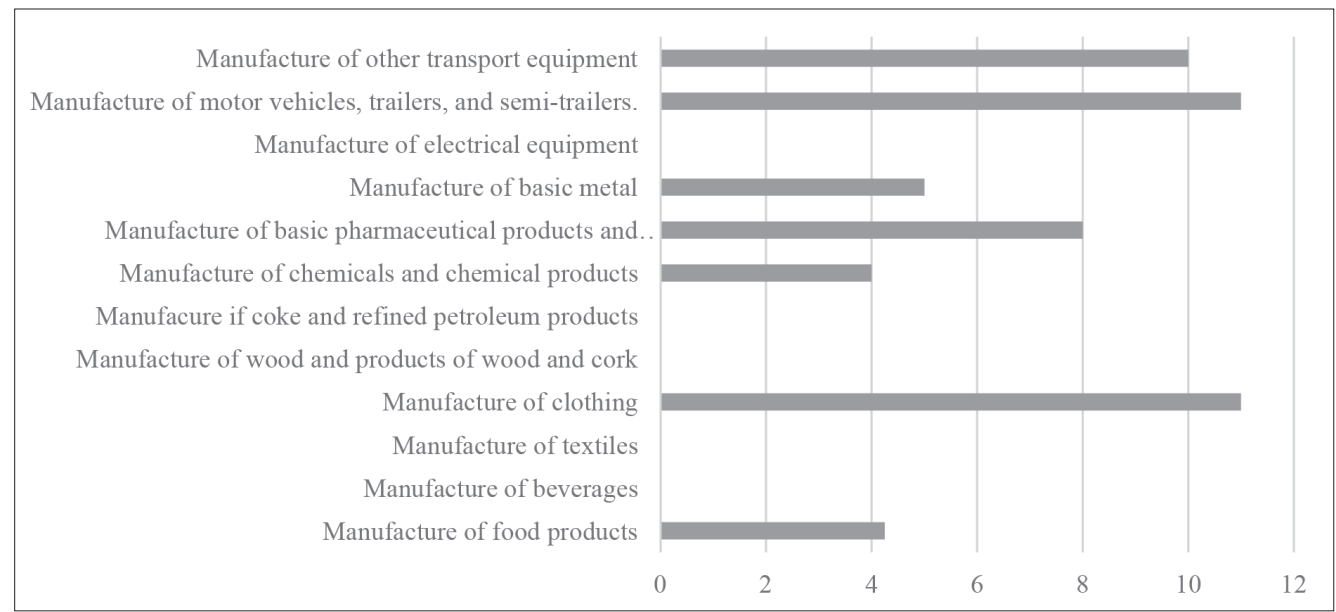

Source: Prepared by authors

Out of the total number of companies presenting pollution-related information in their reports, companies in subsectors Manufacture of motor vehicles, trailers and semi-trailers and 
Manufacture of clothing, report mostly about environmental pollution, i.e. 11 pieces of information on average (note that in this case only companies in 7 subsectors were analysed since companies in the remaining 5 subsectors do not report pollution-related information).

Graph 3. Sustainability information by subsectors

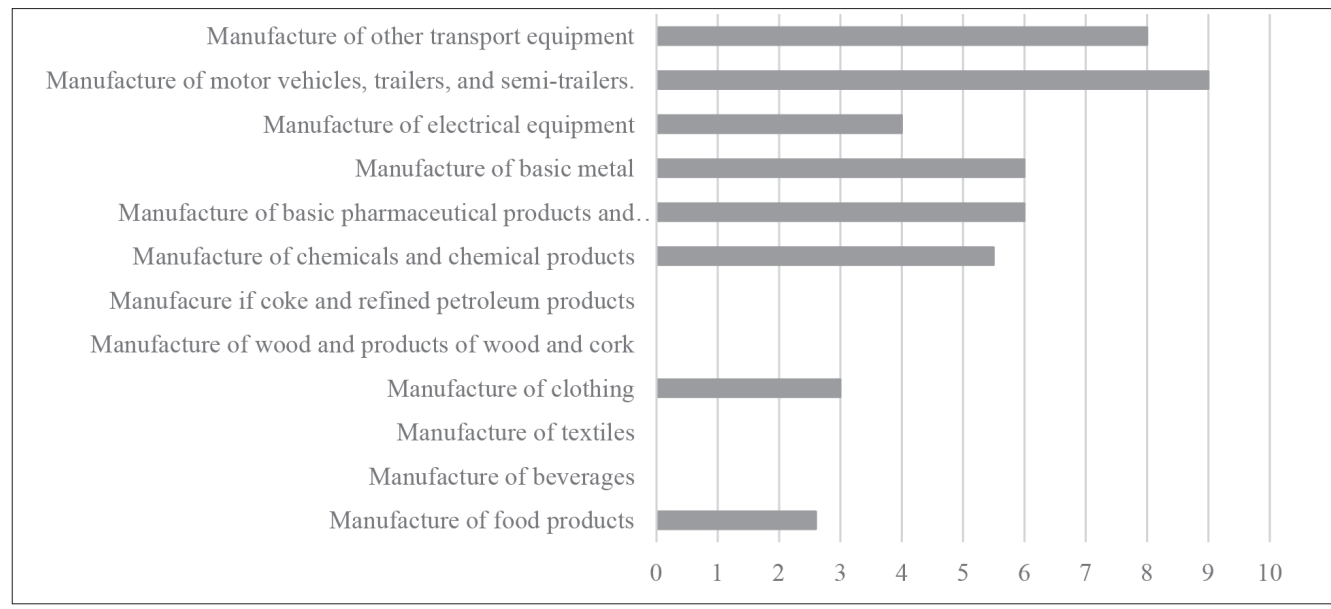

Source: Prepared by authors

Companies engaged in the Manufacture of motor vehicles, trailers and semi-trailers subsector stand out as the ones that report most about sustainability, recycling and natural resource stocks (mean $=9$ ).

Graph 4. Other environmental information by subsectors

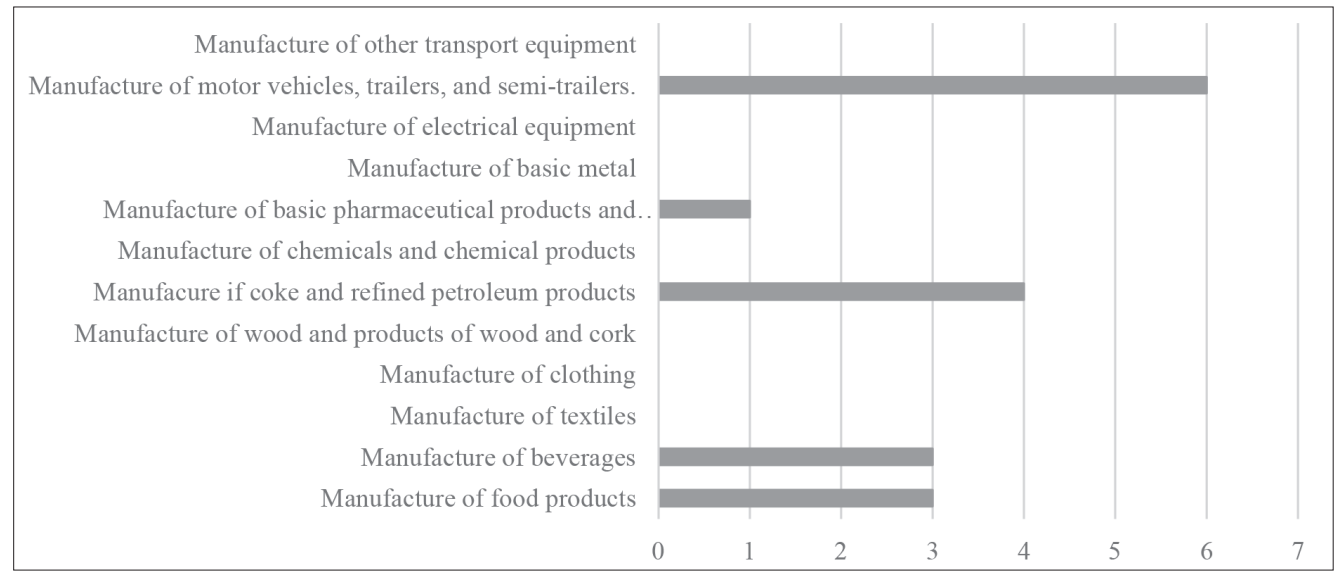

Source: Prepared by authors

Other environmental information is the least reported information in financial statements of the companies surveyed and is accordingly present in only 5 subsectors of the manufactu- 
ring industry. Reports submitted by companies in the Manufacture of motor vehicles, trailers and semi-trailerssubsector contain the largest number of information on environmental investments and expenditures (mean $=6)$.

Based on the aforementioned, hypothesis 3 is not rejected, i.e.companies in the manufacturing sector differ in subsectors with respect to environmental reporting.

\section{DISCUSSION}

The results obtained by researching EA in the listed manufacturing companies in the Republic of Croatia indicate that manufacturing companies do not use environmental accounting sufficiently (43.24\% of companies do not report environmental information), which consequently results in insufficient environmental reporting. According to the results obtained by Krivačić, if the results are compared with all Croatian listed companies, it can be seen that only less than half of the companies have continuously reported on the environment for more than 5 years. ${ }^{25}$ This indicates that the implementation of EA has not increased on the basis of legal regulations, i.e. companies do not meet the statutory environmental reporting obligation.

Based on the above, what is recommended is a more thorough audit of financial statements of those companies that are obliged to disclose non-financial information in the Republic of Croatia. Pursuant to Accouting Act, in January 2018, the Governing Council of the Croatian Audit Chamber issued Guideline 11 -The Auditor's Report on Non-Financial and Diversity Informationin which paragraph 10 provides for an independent auditor or auditing firm that must check, within the scope of a statutory audit, whether the non-financial report was prepared and included in the management report or whether it was prepared and presented as an unconsolidated non-financial report. ${ }^{26}$ In doing so, the auditors check only whether the non-financial report, and hence the environmental report, was prepared or not, without checking the contents of the report. In addition, if for some reason companies fail to report on the environment, they are required to state justified reasons why they do not do that. Since the provisions of Article 20 of the Accounting Act do not apply to non-financial statements of companies, the responsibility for environmental reporting is borne by company management. If the environmental reporting obligation remains in this form, it will not be possible to compare companies both with each other and with companies on the international market. Accordingly, company management is encouraged to apply EA by means of a more systematic verification of the contents of non-financial reports and the future environmental reporting options, i.e. legally defined report forms. It is recommended to follow the Global Reporting Initiative (GRI) guidelines that are internationally recognised and have their own database. Fundamental financial statements are stipulated equally for all companies irrespective of the activity they carry out, and this should also apply to environmental reporting as well as to non-financial reporting in general.

25 Krivačić, D., Sustainability reporting quality: the analysis of companies in Croatia, Journal of Accounting and Management, Vol. 7, No. 1, 2017, p. 7. 


\section{CONCLUSION}

As part of non-financial reporting, environmental reporting has become an integral part of insight into the company's overall business.

By testing the hypotheses, all aims of the paper have been achieved. The limitation related to this research is that a large number of manufacturing companies (43.24\%) were excluded from the sample due to the lack of environmental information in their reports. In order to gain a broader insight and identify differences in individual manufacturing sectors of listed companies as well as companies in other sectors of the Republic of Croatia that do not necessarily have to be manufacturing, future research into the application of EA in Croatian companies should be focused on other sectors manufacturing companies belong to. It is necessary to adjust the method of measurement, since non-manufacturing companies differ from manufacturing companies by their characteristics.

Legislation related to environmental reporting has been applied for a relatively short period of time so the limitation of this study is that it currently refers to reports for only one reporting year.Consequently, the implementation of EA will be comparable in the forthcoming periods based on a more comprehensive analysis and comparison of several reporting years.

It is recommended to repeat this research in the future to determine the difference concerning the use of EA in manufacturing companies over the years and to carry out a survey of audit reports with a view to determining the level of environmental reporting control in the reports of companies subject to such reporting in the Republic of Croatia.

\section{REFERENCES}

1. Accounting Act, Official Gazette No. 120/2016.

2. Bailey, P. E.; Soyka, P. A., Environmental accounting - making it work for your company, Environmental Quality Management, Vol. 5, No. 4, 1996, pp. 13-30.

3. Bewley, K.; Li, Y., Disclosure of environmental information by Canadian manufacturing companies: a voluntary disclosure perspective, Advances in Environmental Accounting \&Management, Vol. 1, 2000, pp. 201-226.

4. Burritt, R. L.; Herzig, C.; Schaltegger, S.; Viere, T., Diffusion of environmental management accounting for cleaner production: evidence from some case studies, Journal of Cleaner Production, Vol. 224, July, 2019, pp. 479-491.

5. European Parliament, Official Journal of the European Union - Directive No. 2014/95/EU.

6. Governing Council of the Croatian Audit Chamber, Guideline 11 -TheAuditor's Report on Non-Financial and Diversity Information, 2018, URL=http://www.revizorska komora.hr/pdf/Smjernice/Smjernica\%2011-180117-2Konacna\%20Smjernica\%2011-rev\%20izvj\%20iNFI.pdf. Accessed 3 September 2018.

7. Hernádi, B. H., Green Accounting for Corporate Sustainability, Theory, Methodology, Practice, Vol. 8, No. 2, 2012, pp. 23-30. 
8. Hylander, L. D.; Goodsite, M. E., Environmental costs of mercury pollution, Science of the Total Environment, Vol. 368, No. 1, 2016, pp. 352-370.

9. Jankovic, S.; Persic, M.; Zanini Gavranic, T., Framework for development of environmental management accounting in Croatian hospitality industry. Sustainable Tourism: Socio-Cultural, Environmental and Economics Impact, Vol. 1, 2011, pp. 121-135.

10. Jasch, C., The use of Environmental Management Accounting (EMA) for identifying environmental costs. Journal of Cleaner production, Vol. 11, No. 6, 2003, pp. 667-676.

11. Krivačić, D., Sustainability reporting quality: the analysis of companies in Croatia, Journal of Accounting and Management, Vol. 7, No. 1, 2017, pp. 1-14.

12. Jing, H.; Songqing, L., The research of environmental costs based on activity based cost, Procedia Environmental Sciences, Vol. 10, 2011, pp. 147-151.

13. Jones, M. J., Accounting for the environment: Towards a theoretical perspective for environmental accounting and reporting, Accounting Forum, Vol. 34, No. 2, 2010, pp. 123-138.

14. Lu, Ying J., A study of environmental disclosures made by Chinese mineral extraction corporations, University of Wollongong Australia, 2008, Res thesis.

15. Pekanov Starčević, D.; Zrnić, A.; Mihalina, E., Environmental Accounting in Croatia: A Review of Corporate Reporting Practices. Interdisciplinary Management Research XIV, 2018, pp. 1396-1409.

16. Peršić, M.; Janković, S., Menadžersko računovodstvo hotela. Zagreb: Fakultet za turistički i hotelski menadžment u Opatiji i Hrvatska zajednica računovođa i financijskih djelatnika Zagreb, 2006.

17. Pramanik, A. K.; Shil, N. C.; Das, B., Environmental accounting and reporting with special reference to India. The Cost and Management, Vol. 3, No. November-December, 2007, pp. 16-28.

18. Qureshi, D. N. Z.; Kulshrestha, D. D.; Tiwari, S. B., Environmental accounting and reporting: An essential component of business strategy, Asian Journal of Research in Banking and Finance, Vol. 2, No. 4, 2012, pp. 85-95.

19. Vasile, E.; Man, M., Current dimension of environmental management accounting. Procedia-Social and Behavioral Sciences, Vol. 62, October, 2012, pp. 566-570.

20. Wilmshurst, T. D.; Frost, G. R., Corporate environmental reporting: A test of legitimacy theory, Accounting, Auditing \& Accountability Journal, Vol. 13, No. 1, 2000, pp. 10-26.

21. Wiseman, J., An evaluation of environmental disclosures made in corporate annual reports, Accounting, Organizations and Society, Vol. 7, No. 1, 1982, pp. 53-63.

22. Yakhou, M.; Dorweiler, V. P., Environmental accounting: an essential component of business strategy, Business Strategy and the Environment, Vol. 13, No. 2, 2004, pp. 65-77.

23. Zagreb Stock Exchange, URL=http://www.zse.hr/default.aspx?id=36769. Accessed 2 September 2018. 
Ana Zrnić*

Dubravka Pekanov Starčevič**

Ivo Mijoč***

\section{OCJENA RAČUNOVODSTVA OKOLIŠA I IZVJEŠTAVANJE O OKOLIŠU: SLUČAJ HRVATSKIH PROIZVODNIH KOTIRAJUĆIH PODUZEĆA}

\section{Sažetak}

Važnost računovodstva okoliša prepoznata je na globalnoj razini te je izvještavanje o okolišu postalo obvezno zakonskom regulativom. Implementacija računovodstva okoliša rezultira okolišnim informacijama koje su postale dio nefinancijskog izvještaja poduzeća, a time i element u stvaranju cjelovitog prikaza poslovanja poduzeća. Cilj je ovoga rada istražiti računovodstvo okoliša i izvještavanje o okolišu u kotirajućim proizvodnim poduzećima Republike Hrvatske. Analizira se način na koji poduzeća izvještavaju o okolišu te zastupljenost okolišnih informacija u financijskim izvještajima za 2017. godinu kotirajućih poduzeća Republike Hrvatske, s naglaskom na proizvodnim poduzećima kao onima koja imaju najviše utjecaja na okoliš. Rezultati pokazuju da kotirajuća proizvodna poduzeća ne koriste računovodstvo okoliša u dovoljnoj mjeri, što posljedično dovodi do nedovoljnog izvještavanja o okolišu. Proizvodna kotirajuća poduzeća u Republici Hrvatskoj najviše izvještavaju o okolišnim informacijama na kvantitativan način. Analizirajući okolišne informacije utvrđeno je da izvješća poduzeća najčešće sadrže informacije o zagađenju i ispušnim plinovima, dok je informacija o održivosti najmanje zastupljena. Također, premalo poduzeća izvještava o održivosti vezanoj uz zalihe prirodnih resursa i potrošnji te recikliranju. Stoga je jasno da je briga o prirodnim resursima i zaštiti okoliša za buduće generacije nisko na listi prioriteta menadžmenta u kotirajućim proizvodnim poduzećima Republike Hrvatske. Istraživana poduzeća različito izvještavaju o okolišnim informacija, a u ovisnosti o djelatnosti kojoj pripadaju. Nadalje, implementacija računovodstva okoliša i izvještavanje o okolišu nije se povećalo na temelju zakonske regulative.

Ključne riječi: $\quad$ računovodstvo okoliša, izvještavanje o okolišu, kotirajuća poduzeća, proizvodna poduzeća

\section{(c) (1) (8)}

This work is licensed under a Creative Commons

Attribution-NonCommercial 4.0 International License.

* Ana Zrnić, univ. spec. oec., asistentica, Ekonomski fakultet u Osijeku, Sveučilište Josipa Jurja Strossmayera u Osijeku, Trg Ljudevita Gaja 7, 31000 Osijek, Republika Hrvatska. Adresa e-pošte: ana.zrnic@efos.hr.

** Dr. sc. Dubravka Pekanov Starčević, izvanredna profesorica, Ekonomski fakultet u Osijeku, Sveučilište Josipa Jurja Strossmayera u Osijeku, Trg Ljudevita Gaja 7, 31000 Osijek, Republika Hrvatska. Adresa e-pošte: dubravka.pekanov@efos.hr.

*** Dr. sc. Ivo Mijoč, izvanredni profesor, Ekonomski fakultet u Osijeku, Sveučilište Josipa Jurja Strossmayera u Osijeku, Trg Ljudevita Gaja 7, 31000 Osijek, Republika Hrvatska. Adresa e-pošte: ivo.mijoc@efos.hr. 